\title{
Konwencja o ochronie i zrównoważonym rozwoju Karpat
}

W 2003 r. w Kijowie została podpisana konwencja o ochronie i zrównoważonym rozwoju Karpat, zwana konwencją karpacką. Konwencję tę podpisali przedstawiciele rządów Czech, Węgier, Polski, Słowacji, Rumunii, Ukrainy, a także Serbii i Czarnogóry. Konwencja ta, podobnie jak konwencja o ochronie Alp z 1991 r., wpisuje się w założenia o gospodarowaniu na terenach górskich, sformułowanych $w$ trzynastym rozdziale Agendy 21, przyjętej w Rio de Janeiro w 1992 r. W ramach programu "Srodowisko dla Europy" Unia Europejska podejmuje poszczególne inicjatywy regionalne. Jedną $z$ nich była deklaracja o środowisku i zrównoważonym rozwoju regionu karpacko-dunajskiego, przyjęta w Bukareszcie w 2001 r. Wymienione inicjatywy mają na celu określenie warunków ochrony i rozwoju wybranych ekosystemów Europy oraz osiągnięcie spójności ekologicznej, np. przez tworzenie paneuropejskiej sieci ekologicznej i krajobrazowej.

Jednym z ważniejszych problemów w Europie jest ochrona i zrównoważony rozwój Karpat, zwanych "Zielonym sercem Europy". Na obszarze ponad 200 tys. kilometrów kwadratowych, należącym do sześciu państw, występują wyjątkowe walory ekologicznych karpackich ekosystemów górskich (rys. 1). Istotnymi cechami tych ekosystemów są: siedliska naturalne i półnaturalne, lasy pierwotne i naturalne, liczne gatunki endemiczne (np. wielkie drapieżniki), strefy źródliskowe bogatej sieci rzecznej, a także bogate dziedzictwo kulturowe. Liczne obszary kwalifikowane jako ekologicznie wrażliwe wymagają wspólnej polityki ochrony i zrównoważonego rozwoju.

Dla wzmocnienia tych działań została przyjęta konwencja karpacka. Strony (państwa) przystępujące do konwencji zobowiązały się „współpracować na rzecz ochrony i zrównoważonego rozwoju Karpat w celu między innymi poprawy jakości życia, wzmocnienia miejscowej gospodarki i społeczności lokalnych oraz zachowania walorów przyrodniczych i dziedzictwa kulturowego". Osiągnięcie tych celów ma nastąpić poprzez podejście ekosystemowe i zintegrowane. Podejście ekosystemowe pole-

Komitet „Człowiek i Środowisko" PAN w Warszawie. 


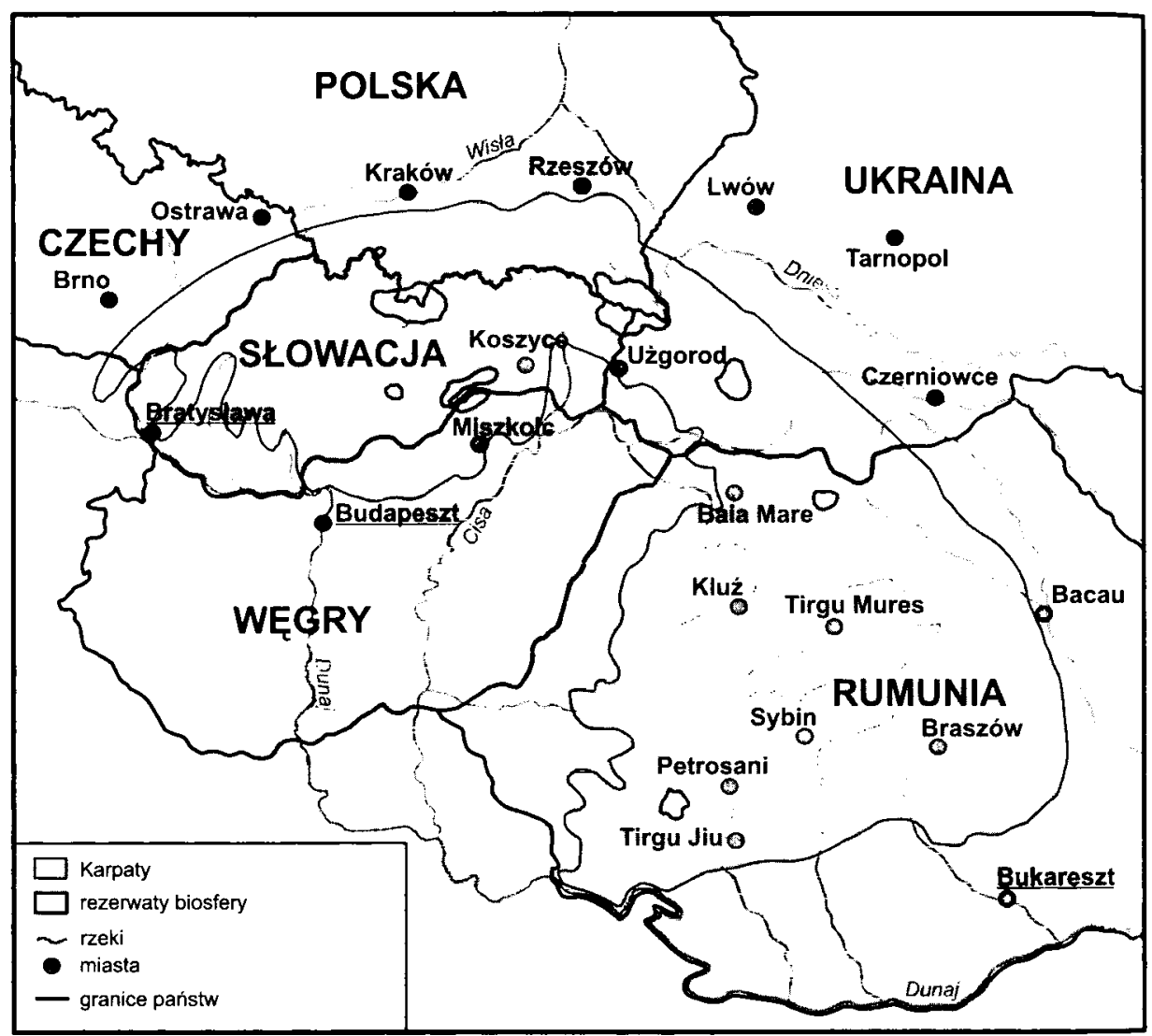

Rys. 1. Rezerwaty biosfery w Karpatach.

-ródło: Instytut Ochrony Środowiska, Ośrodek Informacji o Ochronie Środowiska, Warszawa, maj 1997

ga na wyodrębnieniu dużych ekosystemów, np. systemu górskiego. Za obszar górski uważa się tereny położone powyżej określonej wysokości nad poziom morza. Obecnie zwiększone dopłaty dla rolnictwa dotyczą obszarów położonych powyżej $500 \mathrm{~m}$ n.p.m. W kwalifikacji ekoregionu karpackiego stosuje się też wysokość 350 m n.p.m. (rys. 2). Podejście zintegrowane polega na koordynacji różnych polityk sektorowych (rolnych, leśnych, wodnych, transportowych, przemysłowych) zgodnie z założeniami zrównoważonego rozwoju. Podejście to ma szczególne znaczenie $\mathrm{w}$ planowaniu przestrzennym i w zastosowaniu do gospodarki zlewniowej. Realizacja tego postulatu wymaga koordynacji sektorowej (różnych ministerstw), regionalnej (strategii wojewódzkich), a także na poziomie międzynarodowym. $Z$ tego względu wyłania się potrzeba formulowania wspólnej polityki społeczno-gospodarczo-ekologicznej dla obszaru objętego wspólną konwencją, w tym przypadku konwencją karpacka. 


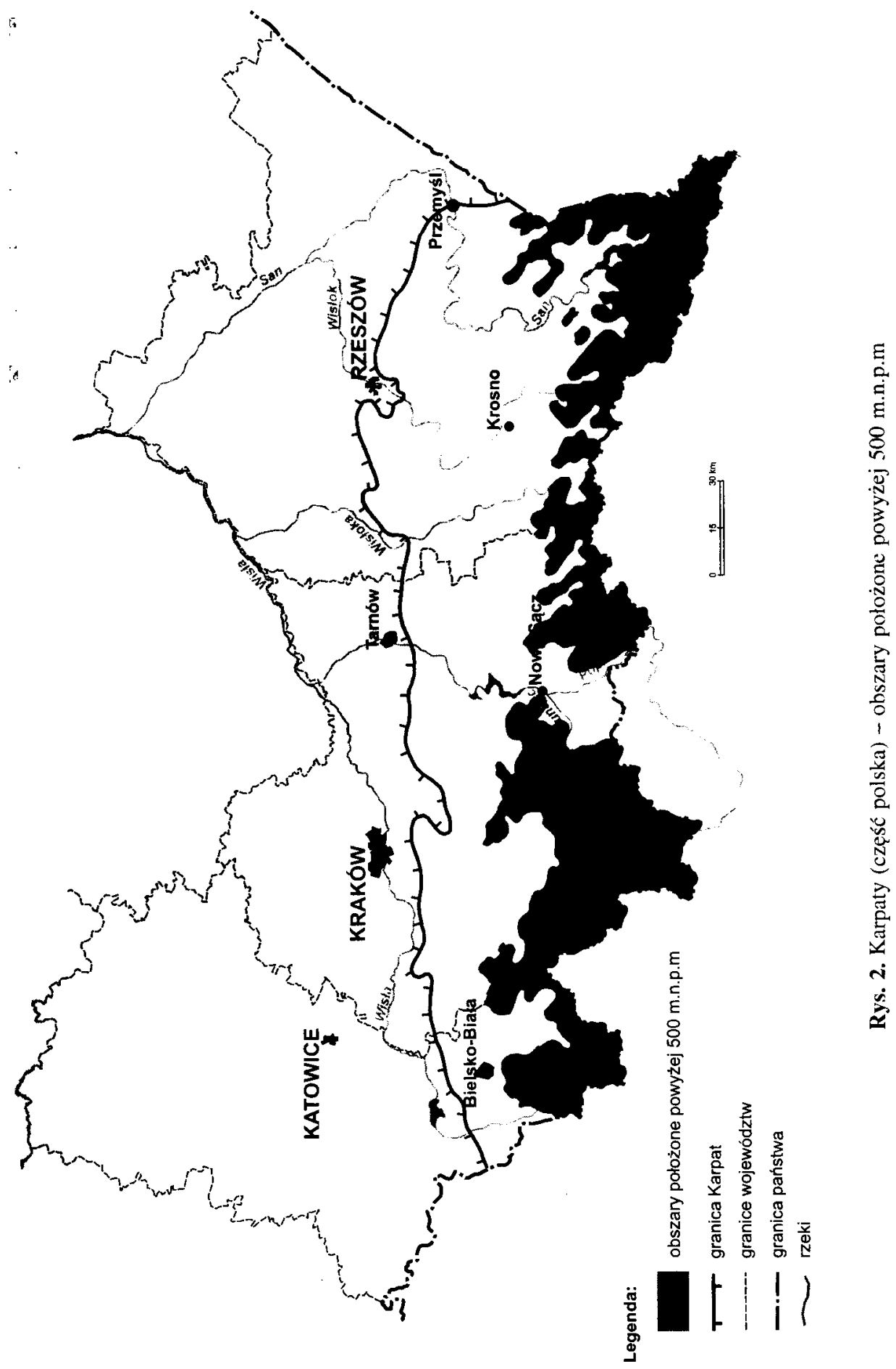


Konwencja karpacka zakreśliła już ramy takiej wspólnej polityki. Dotyczy ona następujących działów:

1. Zintegrowane podejście do gospodarowania zasobami ziemi. Jeden $z$ wniosków mówi, że „strony będą promować utrzymywanie półnaturalnych siedlisk, odtwarzanie pierwotnego stanu siedlisk zdegenerowanych oraz wspieranie opracowywania i realizacji odpowiednich planów zarządzania".

2. Planowanie przestrzenne. Głównym celem ma być ochrona i zrównoważony rozwój Karpat. Potrzebna będzie koordynacja na terenach przygranicznych, realizacja programów transgranicznych (międzynarodowych). Oznacza to potrzebę opracowania wspólnych międzynarodowych standardów planistyczno-urbanistycznych dla ekoregionu karpackiego. Zintegrowane planowanie przestrzenne dla tego ekoregionu powinno posiadać również ujednolicone kryteria wykonywania ocen oddziaływania na środowisko, szczególnie w zakresie transgranicznych zanieczyszczeń środowiska (np. dopływ zanieczyszczonego powietrza do Polski z kierunku południowego).

3. Zrównoważone i zintegrowane zarządzanie wodami dorzecza. Pełna realizacja Ramowej Dyrektywy Wodnej ma szczególne odniesienie w stosunku do obszaru karpackiego. Karpaty są obszarem źródliskowym dla wielu rzek, toteż ochrona źródeł i naturalnych cieków wodnych ma szczególne znaczenie. Dobry stan ekologiczny wód płynących powinien obejmować jak najdłuższe odcinki rzek. Ochrona tych cieków powinna być traktowana priorytetowo, np. przy rozdziale środków na gospodarkę wodną w poszczególnych województwach. Oznacza to konieczność radykalnej zmiany dotychczasowej polityki inwestycyjnej w gospodarce wodnej. Zasadniczej zmianie powinien też ulec dotychczasowy sposób wydatkowania pieniędzy na usuwanie zagrożeń i skutków powodzi. Zamiast prostować i betonować górskie potoki, potrzebna jest realizacja planów zarządzania zlewniami, w których zapisano by takie działania, jak zwiększanie lesistości i budowę suchych zbiorników przeciwpowodziowych.

4. Zrównoważone rolnictwo i leśnictwo. Przewiduje się utrzymywanie tradycyjnych sposobów upraw rolnych i hodowlę starych ras. Karpaty powinny być bardziej nasycone obszarami rolnośrodowiskowymi. Dla karpackich ekosystemów górskich potrzebne są odrębne programy uwypuklające ekologiczną funkcję lasów. Dotyczy to głównie lasów pierwotnych i naturalnych. W Karpatach powinien być znacznie większy udział lasów chronionych, a także powinna być znacznie większa lesistość. $Z$ tego powodu istnieje potrzeba nowego ujęcia programu zwiększenia lesistości w Polsce. Zwiększenie lesistości Karpat ma doprowadzić do zdecydowanego ograniczenia zagrożeń powodziowych. 
5. Zrównoważony transport i infrastruktura. Realizacja zadań inwestycyjnych musi uwzględniać specyfikę środowiska terenów górskich, a zwłaszcza obszarów wrażliwych ekologicznie, o dużej różnorodności biologicznej, szlaków wędrówek zwierząt, a także o szczególnym znaczeniu dla turystyki. Na obszarze Karpat mają być stosowane modele transportu przyjaznego dla środowiska i minimalizujące szkodliwe oddziaływanie na zdrowie ludzkie.

6. Przemysł i energia. Na terenie Karpat mają być promowane technologie czystszej produkcji. Dotyczy to metod produkcji, wykorzystania energii oraz dystrybucji, a także rozwiązań energooszczędnych i wykorzystania odnawialnych źródeł energii, np. geotermii.

7. Zrównoważona turystyka. W Karpatach promowana będzie zrównoważona turystyka, przynosząca korzyść miejscowej ludności, oparta „na wyjątkowym charakterze przyrody, krajobrazu i dziedzictwa kulturowego Karpat". Promowana będzie współpraca transgraniczna. W tym celu potrzebna będzie koordynacja „wspólnych planów zarządzania transgranicznymi lub przygranicznymi obszarami chronionymi oraz innymi terenami o walorach turystycznych".

8. Dziedzictwo kulturowe. Konieczne jest "zachowanie i promowanie dziedzictwa kulturowego i wiedzy ludowej, wyrobów artystycznych i rękodzielniczych", a także tradycyjnej architektury i sposobów użytkowania ziemi, np. pasterstwo.

Dla realizacji powyższych zadań konwencja przewiduje wprowadzenie wspólnego systemu ocen oddziaływania na środowisko, systemu wczesnego ostrzegania oraz informowania i monitorowania zmian zachodzących w środowisku. Oznacza to potrzebę stosowania wspólnych ocen ryzyka i ocen oddziaływania na środowisko, ze szczególnym uwzględnieniem strategicznych ocen oddziaływania na środowisko. Konieczna będzie harmonizacja istniejących i opracowanie nowych wskaźników środowiskowych i społeczno-gospodarczych. Oznacza to potrzebę współpracy w prowadzeniu badań i ocen naukowych w Karpatach, np. w zakresie standaryzacji metod badawczych.

Ważnym zadaniem konwencji jest podnoszenie świadomości ekologicznej i poprawy dostępu społeczeństwa do informacji o ochronie i zrównoważonym rozwoju Karpat. Dotyczy to także promowania szkolnych i innych programów edukacyjnych.

Przedstawione główne idee konwencji karpackiej wskazują na jej bardzo szeroki zakres tematyczny, wymagający poważnych działań integrujących. Realizacja tych zadań wymaga bardzo szybkiego ratyfikowania przez Polskę tej konwencji.

Konieczne jest też opracowanie założeń dla strategii i zrównoważonego gospodarowania w polskich Karpatach. Obecnie pod patronatem głównego konserwatora przyrody, prof. Zbigniewa Witkowskiego po- 
dejmowane są w Krakowie prace w ramach Forum Wspólpracy Zielone Karpaty.

Kolejnym krokiem powinna być integracja strategii rozwoju trzech województw: podkarpackiego, małopolskiego i śląskiego np. w postaci porozumienia trzech marszałków na wzór porozumienia funkcjonującego dla Zielonych Płuc Polski.

\section{The Convention for protection and sustainable development of Carpathian Mountains}

\section{SUMMARY}

Article comprehends description of coming into being The Convention for protection and sustainable development of Carpathian Mountains. It leads analysis of essences of this Convention and shows its importance for this part of Europe and for Poland. The article points also at perspective and possibility putting into execution of Convention resolutions. 